Debreceni Jogi Múhely 2015. (XII.) 3-4.

Debreceni Egyetem, Állam- és Jogtudományi Kar, Debrecen

(University of Debrecen, Faculty of Law, Debrecen)

DOI 10.24169/DJM/2015/3-4/12

\title{
Fegyveresi Zsolt
}

óraadó, Sapientia Erdélyi Magyar Tudományegyetem,

Magánjogi és összehasonlító Jogi Intézet

PhD hallgató, Debreceni Egyetem, Marton Géza Állam- és Jogtudományi Doktori Iskola

\section{Recenzió}

Manuel Guțan:

Sisteme de drept comparate. Introducere în teoria generală a dreptului comparat (Összehasonlító jogrendszerek. Bevezetés az összehasonlító jog általános elméletébe)

\author{
Bukarest, Hamangiu Kiadó, 2014, 357 oldal
}

ISBN: 978-606-27-0078-2

Debreceni Jogi Műhely, 2015. évi (XII. évfolyam) 3-4. szám (2015. december)

DOI $10.24169 / \mathrm{DJM} / 2015 / 3-4 / 12$

Ma már nem újdonság az, hogy a modern világban, különösen a korszerủ kommunikációs eszközöknek köszönhetően, a politikai, kulturális és gazdasági akadályok folyamatos felszámolásának lehetünk tanúi. Az egységesítés, a szabványosítás, az integráció és a globalizáció fogalmaival egyre gyakrabban találkozunk, úgy globális, mint regionális szinten. A személyek, az áruk és a tőke szabad mozgásával egyre inkább figyelmen kívül maradnak a nemzeti határok. A nemzetközi kapcsolatok évről-évre egyre nagyobb teret hódítanak. A jog területén ezt az ismeretelméleti szerepet az összehasonlító jog tölti be.[1]

Manuel Gutan a Szebeni Tudományegyetem Jogi Fakultásának docense. Könyve tankönyvnek készült és a hallgatók számára kívánt segédanyagként szolgálni a vizsgákra való felkészülésben. Gutan könyve azonban sokkal több mint egy egyetemi tankönyv, innovatív és ugyanakkor hiánypótló munka tematikája kapcsán a romániai jogi szakirodalomban. A szerző megpróbálja megmagyarázni az olvasónak, hogy az összehasonlító jog nem csak egy leírás arról, hogy egyes külföldi jogrendszerek hogyan szabályozzák a különböző jogintézményeket. Gyakran megfeledkeznek arról, hogy az összehasonlitás nem csak egymás mellé helyezést, a hasonlóságok és különbségek kiemelését jelenti a különbözó jogrendszerek és jogintézmények között.

A klasszikus értelemben vett összehasonlító jogi technikák támogatói számára az összehasonlítás nem több mint egy tudományos szemlélet, amely nem igényel különösebb módszertani szakértelmet. Ebben az összefüggésben a szerző egy másik szempontot és nyomvonalat képvisel. Könyvében egy bevezetőnek szánt minimáliselméleti alapot kíván nyújtani, ami elmaradhatatlan az olvasó számára ahhoz, hogy az jobban megértse, elsajátítsa és elmélyítse az összehasonlító jog területén szerzett ismereteit. A szerző arra is figyelmeztet, hogy a könyv elolvasása és tanulmányozása még nem elegendő ahhoz, hogy egy teljes képet kapjunk az összehasonlító jog területéről és nem is sajátíthatjuk el a könyv alapján az összehasonlítás tudományának teljes tárházát. Ehhez a szerző bevallása szerint is hosszú évekre és tömérdek kutatásra van szükségünk. A könyv viszont segít abban, hogy az összehasonlító jog területe iránt érdeklődők hol is kezdhetik el és milyen utat kell bejárniuk ahhoz, hogy elsajátíthassák az összehasonlító jogi elemzés tudományát. 
Debreceni Jogi Mühely 2015. (XII.) 3-4.

Debreceni Egyetem, Állam- és Jogtudományi Kar, Debrecen

(University of Debrecen, Faculty of Law, Debrecen)

DOI 10.24169/DJM/2015/3-4/12

A könyv központi témája az összehasonlító jog elméleti kérdéseinek elemzése és ismertetése. A szerző könyvét kilenc fejezetre strukturálta, olyan kérdésekre keresve a választ, mint: mit is hasonlítunk össze, mi az összehasonlító jog tárgya, milyen kapcsolatban van az összehasonlító jog más jogi tudományokkal, mi nem az összehasonlító jog, miért van szükségünk és mi a funkciója az összehasonlító jognak, stb.

A könyv első fejezetében a szerző az összehasonlító jog történeti fejlődését vizsgálja. A jogi összehasonlítás szemlélete és ennek módszertana, a különböző jogrendszerek közötti különbségek és hasonlóságok előtérbe kerülésének kezdeti időpontját a XIX. század első felére tehetjük. A szerző szerint az 1850-es évekre fedezik fel a különböző jogrendszerek másságát és kezdenek el ezekkel tudományos szinten is foglalkozni. Az összehasonlító jog ebben a periódusban a tudományos és filozófiai kíváncsiság eszköze. A nemzeti vagy belső jogszabályok megreformálása ösztönözte az összehasonlító jogi elemzés kialakulását és fejlődését.[2] Manuel Gutan kiemeli, hogy számos esetben, így Angliában is, a jogi összehasonlítás gyakorlati igényeknek kívánt megfelelni.[3] Franciaországban 1869-ben megalapítják a Société de Legislation Comparée nevü társaságot, melynek periodikája mai napig megjelenik Revue internationale de droit comparé címen. A francia mintát követve Németországban 1894-ben Internationale Vereinigung fur vergleichende Rechitswissenchaft und Volkswirtschaftehrenéven, Angliában pedig szintén 1894-ben The Society of Comparative Legislationnéven társaságot alapítanak.

1900-ban Párizsban a világkiállítás évében megrendezésre került a Nemzetközi Összehasonlító Jogi Kongresszus.Ez a rendezvény meghatározó mérföldkő az összehasonlító jog tudományának fejlődésében. A kongresszus két kiemelkedő személyisége Raymond Saleilles és Edouart Lambert. A XX. század első felében az összehasonlító jogi megközelítés központi kérdése a nemzeti és nemzetközi jog egységesítése. A cél az emberiség közös jogának a megteremtése, a világjog megalkotása, amelyben az összehasonlító jognak központi szerepet szánnak. A jogi hasonlóság és az egységesség kerül középpontba, a sokszínűség és pluralizmus rovására. A második világháborút követően az összehasonlító jog robbanásszerű fejlődésnek indult. Számos intézmény alakul, konferenciákat és kongresszusokat szerveznek, szakfolyóiratok látnak napvilágot és megkezdődik az összehasonlító jog oktatása a különböző jogi karokon.

A tankönyv második fejezetében a szerző olyan kérdésekre próbál választ adni, mint: melyek az összehasonlító jog összetevői, hogyan fejlődött és alakult ki az összehasonlító jog, mi az összehasonlító jog funkciója és célja, miként különböztethető meg az összehasonlító jog más jogi tudományoktól, melyek az összehasonlító jog elméleti alapjai, stb. Ezen kérdések megválaszolására a szerző olyan összehasonlító jogi szakemberek munkáira támaszkodik, mint Myres Smith McDougal, René David, H.C. Gutteridge, Edouart Lambert, Konrad Zweigert.[4]

A könyv harmadik fejezetében az összehasonlító jog definíciójára vállalkozik a szerző a különböző összehasonlító jogi irányzatok ismertetésén keresztül. Az összehasonlító jogról megfogalmazott különböző elméletek fényében két doktrinális tendencia mutatkozik meg. Ezek értelmében beszélhetünk összehasonlító jogról mint tudományról és összehasonlító jogról mint módszerrôl, de nem feledkezhetünk meg a jogi oktatásban betöltött fontos funkciójáról sem. Az összehasonlító jog törvényhozó segítség, az értelmezés és a jogegységesítés eszköze.

Mit hasonlítunk össze? Mi az összehasonlító jog tárgya? A tankönyv negyedik fejezetében a szerző ezekre a kérdésekre keresi a választ. Túl egyszerűen hangzik az a válasz, hogy az összehasonlító jog tárgya maga a jog (Zweigert és Kötz), vagy tágabb értelemben a jogtudományok (René David). Az összehasonlító jog tárgyát számos esetben az határozza meg, hogy módszerként ezt éppen milyen jogterületen alkalmazzuk. Úgy is fogalmazhatnánk, hogy az összehasonlító jognak annyi tárgya van, ahány „komparatista” létezik, ezek felsorolása szinte lehetetlen. A szerző szerint egyszerűbb feladatnak bizonyul annak a meghatározása, 
Debreceni Jogi Múhely 2015. (XII.) 3-4.

Debreceni Egyetem, Állam- és Jogtudományi Kar, Debrecen

(University of Debrecen, Faculty of Law, Debrecen)

DOI 10.24169/DJM/2015/3-4/12

hogy mi nem képezheti az összehasonlító jog tárgyát. Így például nem beszélhetünk összehasonlító jogról, ha valaki csak saját nemzeti jogrendszerét kutatja. Zweigert és Kötz értelmezése szerint össze lehet hasonlítani egy adott jogrendszer különböző szabályait, ebben az esetben azonban nehéz lenne elhatárolni attól a minden nemzeti jogrendszerre jellemző tevékenységtől, amit egy adott nemzet jogászai nap mint nap tesznek. Az összehasonlító jog lényege tehát nem ebben áll, valamiféle plusz tartalommal kell bírnia. Ez pedig nem más, mint az „internacionalizmus”.[5]Ellentétes vélemények is megfogalmazódtak. Így például egy föderáció tagállamainak, vagy a különböző svájci kantonok joga, de az Amerikai Egyesült Államok tagállamainak joga is képezheti az összehasonlító jog tárgyát. Ezt a fajta módszert belsố jogösszehasonlításnak nevezték, utalva arra, hogy egy azonos társadalmi rendszer, ugyanannak a jogcsaládnak vagy szövetségi államnak a jogrendszeréről van szó.[6]

Számos kutató azon a véleményen van, hogy különbséget kell tenni az összehasonlító jog és a külföldi jog tanulmányozása között, bár látszólag mind a két megközelítés megfelel az ,internacionalizmus” feltételrendszerének. Egy külföldi jog tanulmányozása és kutatása, még nem meríti ki az összehasonlító jogi minősités elemeit. A szerzôvel együtt mi is feltehetjük a kérdést, hogy tulajdonképpen hány különböző nemzeti jogrendszer összehasonlítása szükséges ahhoz, hogy összehasonlító jogról beszélhessünk? A második kérdés, hogy mit akarunk elérni, milyen célt követünk akkor, amikor ezeket a különböző jogrendszereket összehasonlítjuk?A válaszok kibontására jelen recenzió keretén belül nem kerülhet sor, de a kérdésekre két rövid választ a szerző is megfogalmaz, majd ezeket a negyedik fejezet keretei között részletesen is tárgyalja. Az első kérdésre a válasz, hogy két vagy több jogrendszer összehasonlítása szükséges ahhoz, hogy összehasonlító jogról beszélhessünk. Az összehasonlítás célja a közös elemek felismerése és különbségek megállapítása és ezek besorolása különböző jogcsaládok rendszerébe.

A tankönyv ötödik fejezetében a szerző arra keresi a választ, hogy mi nem az összehasonlító jog, és hogy ez milyen kapcsolatban áll más jogi tudományokkal. A különböző definíciók sokszor sterilnek bizonyultak és gyakran ellentmondóak is. Éppen ezért számos esetben a szakirodalom egy negatív definíció megfogalmazására törekedett. Ez a típusú megközelítés eredményezte azt, hogy az összehasonlító jogot fokozatosan elhatárolták más szintén a joggal foglalatoskodó tudományoktól. Meg kell jegyeznünk azonban, hogy azok a „komparatisták”, akik az összehasonlító jogot csak módszerként értelmezik és alkalmazzák, szükségtelennek tartották ezt a típusú megközelítést. Az összehasonlító módszert az általános jogelmélet, a jogfilozófia, a jogtörténet, a jogi etnológia, a jogszociológia, a nemzetközi magánjog és nemzetközi közjog tudományterületein is alkalmazzák.

A hatodik fejezetben az összehasonlító jog szükségszerűségét és funkcióit vizsgálja a szerző. Zweigert és Kötz nyomán Manuel Gutan az összehasonlító jog négy funkcióját tárgyalja: az összehasonlító jog, mint a törvényhozó segítsége (a megismerés és az önismeret funkciója); az összehasonlító jog, mint az értelmezés eszköze (gyakorlati funkció, eszköz a belső jogalkotáshoz, az egységesítés és harmonizációs funkció); az összehasonlító jog, mint egyetemi tantárgy; és az összehasonlító jog, mint a szisztematikus jogegységesítés eszköze.

A könyv hetedik fejezetében az összehasonlító jog módszereit ismerteti a szerző. Minden kognitív folyamat többé-kevésbé tudatosan egy összehasonlító megközelítést feltételez. A tudományokban az összehasonlító módszer a tudás egyik alapvető eszköze. Az összehasonlító módszer bármely területen alkalmazható, a társadalom és természettudományokban egyaránt, új ismeretek megszerzése érdekében. Éppen ezért az összehasonlítás nem rendelkezik saját tartalommal, azaz a tudás egy bizonyos tárgyára alkalmazható. A szerző felhívja a figyelmet arra, hogy nem szabad összetéveszteni az összehasonlítás folyamatát az összehasonlítás eredményeivel. Ezek az eredmények nem tartoznak az összehasonlításhoz, úgy ahogy az összehasonlítás tárgya sem tartozik az összehasonlításhoz, hanem sokkal inkább a tudományhoz és a megszerzett tudáshoz. 
Debreceni Jogi Múhely 2015. (XII.) 3-4.

Debreceni Egyetem, Állam- és Jogtudományi Kar, Debrecen

(University of Debrecen, Faculty of Law, Debrecen)

DOI 10.24169/DJM/2015/3-4/12

Az összehasonlító jog módszerei sajátos vonásokkal rendelkeznek. Különálló szabályok szerint múködnek, melyek részben eltérnek, részben pedig kiegészítik a más tudományok által használt összehasonlító módszereket. A szerző véleménye szerint annak ellenére, hogy nem indokolt az összehasonlító jogról, mint önálló jogi tudományról beszélni, az összehasonlításnak tudományos jelleget kell öltenie. Az összehasonlító jog módszerként értelmezhetô, de nem egy akármilyen, hanem egy szisztematikus és jól megszerkesztett módszerként. Ennek célja új ismeretek megszerzése.[7]

A tankönyv nyolcadik és kilencedik fejezetében a szerző az összehasonlító jog és a jogi transzplantáció,illetve a jog és kultúra viszonyát vizsgálja. Gutan felteszi a kérdést, hogy lehetséges-e a jog importálása és megengedett-e a jog transzplantálása? P. Legrand véleményét idézi, aki szerint a kulturális határok végett a jog „szabad mozgása” nem lehetséges. Egy sajátos környezetben kialakult jogintézmény nem költöztethető benne rejlő kulturális jelentősége miatt. Azzal, hogy egy másik jogrendszerbe átültetik, elveszti sajátosságát és egy más jogintézménnyé válik. Gutan nem ért egyet Legrand állitásaival és úgy véli, hogy a jogi transzplantáció sok esetben szükséges és számos igazságszolgáltatási reform-folyamatnak az alapját képezi. A jogi transzplantáció okai közül a szerző többet is felsorol és néhányat részleteiben is elemez. A transzplantáció egyik legfőbb oka a presztízs. Egy jól működő és elfogadott jogintézmény átvétele sokszor presztízs értékú is. Más esetben a szükség készteti a jogalkotót a transzplantációra, de számos esetben a sürgősség, a kényelem, politikai és gazdasági érdekek vezetnek a jogi transzplantációhoz. Azt is fontos megvizsgálni és szem előtt tartani, hogy honnan importálunk, milyen céllal és milyen mennyiségben, illetve milyen módszereket alkalmazunk a transzplantációban.

Nagy érdeme a könyvnek, hogy a nemzetközi jogi szakirodalom számbavétele után Manuel Gutan a XX. századi román szerzők munkáit is felsorolja és beépíti tankönyvébe. A könyv számos lábjegyzettel és minden fejezet végén részletes irodalomjegyzékkel van ellátva. A romániai összehasonlító jogi oktatásban elengedhetetlenül szükséges munka, de egyaránt hasznos információt nyújt a téma iránt érdeklődő jogász társadalomnak is.

[1] René David-Camille Jauffret-Spinosi: Les grands systémes de droit contemporains, Dalloz, Paris, 1992.

[2] Konrad Zweigert-Hein Kötr: Introduction to Comparative Law, Clarendon Press, Oxford, 1998, 54.

[3] A szerző itt kiemeli a Titkos Tanács (Privy Council)különleges joghatóságából származó szerepét

[4] Smith McDongal: The Comparative Study of Law for Policy Purpose; Value Clarification as an Instrument of Democratic World Order, American Journal of Comparative Law, 1/1952; René David: Traite elementaire de droit civil compare. Introduction a l'etude des droitd etrangeres ea a la methode comparative, Librairie generale de droit et de jurisprudence, Paris, 1950; H.C. Gutteridge: Le droit compare, Librairie generale du droit et de jurisprudence R. Pichon et Durand-Auzias, Paris, 1953; Edouart Lambert. L'idee d'une science universelle du droit compare, Etude de droit contemporain, in Contribution francaise aux IIIe et Ive Congres internationaux de droit compare, Paris, 1959; Konrad Zweigert: Methodologie du droit compare, in Melanges Maury, Paris 1960.

[5] Ezen a véleményen van Kokkini-Iatridou görög jogászprofesszor is, aki kifejti, hogy csak különböző jogrendszerek közötti összehasonlítás méltó arra, hogy az összehasonlító jog tárgyát képezze.

[6] Marc Ancel: Utilite et Methodes du droit Compare, Editions Ides et Calendes, Neuchatel, 1971, 90.

[7] Jean-Leontin Constantinesco: Tratat de drept comparat. Vol. I: Introducere în dreptul comparat, Editura All Kiadó, Bukarest, 1997, 226. 